\title{
The Comstock Books
}

"Our writing was the thread on which our days were strung, despite a thousand interfering activities." ANNA BOTSFORD COMSTOCK

\section{JOHN HENRY COMSTOCK}

1888 An Introduction to Entomology. Illustrations drawn and engraved by Anna Botsford Comstock.

1889 The Elements of Insect Anatomy, with Vernon L. Kellogg.

1895 A Manual for the Study of Insects. Illustrations by Anna Botsford Comstock. Twenty-second edition, 1942.

1897 Insect Life, an introduction to Nature-Study, with Anna Botsford Comstock. Illustrations by Mrs. Comstock.

1904 How to Know the Butterflies, with Anna Botsford Comstock. A manual of the butterflies of the eastern United States.

1912 The Spider Book. A Manual for the Study of Spiders and Their Relatives.

1918 The Wings of Insects. An exposition of the uniform terminology of the wing veins.

1925 An Introduction to Entomology. The development of Entomology before and since his first book was published under the same title. Illustrated.

\section{ANNA BOTSFORD COMSTOCK}

1903. Ways of the Six-footed. Illustrated.

1904 How to Know the Butterflies, with John Henry Comstock. Illustrated. 


\section{APPENDIXES}

1905 How to Keep Bees. Illustrated.

1906 Confessions to a Heathen Idol.

1911 Handbook of Nature-Study. Twenty-fourth edition, 1948.

1914 The Pet Book.

1916 Trees at Leisure.

1920 Nature Notebook Series with outline drawings by Louis Agassiz Fuertes. Seven notebooks in the series: five on birds and plants by Anna Botsford Comstock; one on fish by G. C. Embody; one on insects by James G. Needham.

No complete bibliography of the writings of John Henry Comstock or of Anna Botsford Comstock has been compiled or published. In addition to their books, both contributed articles to scientific publications. For examples, Mrs. Comstock was a contributing editor for The Nature Study Review, 1905-1917, and its editor, 1917-1923; and Professor Comstock edited the entomological section of the American Naturalist, 1887-1889.

GlenN W. Herrick and Ruby Green Smith 
